\title{
Pet-related Pasteurella multocida induced peritonitis in peritoneal dialysis: a case report and review of the literatures
}

\author{
Haoran $\mathrm{Mu}^{1 \dagger}$, Man Yang ${ }^{2+}$, Yueyue Zhang ${ }^{2}$, Yajing Zhang ${ }^{1}$, Juan Wang ${ }^{2}$, Weijie Yuan ${ }^{2}$ and Shu Rong ${ }^{2 *}$
}

\begin{abstract}
Background: P. multocida (Pasteurella multocida) is animal-sourced gram-negative coccobacillus which can be transmitted to human through many animals including household pets. P. multocida induced peritoneal dialysisrelated peritonitis has rarely been reported. In recent years, there has been an increase in the incidence of $P$. multocida induced peritoneal dialysis-related peritonitis, for the reason that patients with PD at home bred household pets. In this study, we present a case of a P. multocida induced peritoneal dialysis-related peritonitis, which is suspected to be caused through intimate contact with a household cat and we have reviewed 28 cases reported before and give suggestions for treatment and the way of prevention.

Case presentation: A 75-year-old man with end-stage renal disease (ESRD) for nearly 5 years on continuous ambulatory peritoneal dialysis (CAPD) was admitted to the nephrology department with a 1-week history of abdominal pain and a cloudy peritoneal dialysis effluent. Based on the history, physical examination and laboratory results with the findings in the peritoneal dialysis fluid, a diagnosis of peritoneal dialysis-related peritonitis was confirmed. The final culture of initial peritoneal effluent results indicated the organism was P. multocida. After a 12day antibiotic treatment, the condition of patient was not improved. The patient was switched to ampicillin/ sulbactam (3 g intravenously) twice every day and the condition was improved significantly. On further inquiring, the patient reported that he had had a cat at home and when the patient did CAPD, the cat was usually playing with the tubing or contacting the patient during CAPD.

Conclusion: In our case and reviewed cases, P. multocida induced peritoneal dialysis-related peritonitis could be cured by proper antibiotic treatment. If individuals keep the pet away from the PD process, the infection route may be severed. P. multocida induced peritoneal dialysis-related peritonitis does not need catheter removal and exchange with hemodialysis except long-time intractable peritonitis.
\end{abstract}

Keywords: Peritoneal dialysis, Peritonitis, Pasteurella multocida, Pet, Cat

\section{Background}

P. multocida (Pasteurella multocida) is animal-sourced gram-negative coccobacillus which can be transmitted to human through many animals including household pets,

\footnotetext{
*Correspondence: sophiars@126.com

${ }^{+}$Haoran $\mathrm{Mu}$ and Man Yang contributed equally to this work.

²Department of Nephrology, Shanghai General Hospital, Shanghai Jiao Tong University School of Medicine, Shanghai 200080, China

Full list of author information is available at the end of the article
}

such as cats [1]. Commonly P. multocida has been reported to cause human soft tissue infection through being bitten by pets and P. multocida induced peritoneal dialysis-related peritonitis has rarely been reported. The first case of infection was reported by Paul and Rostand in 1987 and in recent years, there has been an increase in the incidence of $P$. multocida induced peritoneal dialysis-related peritonitis, for the reason that patients with PD at home bred household pets [2].

C C The Author(s). 2020 Open Access This article is licensed under a Creative Commons Attribution 4.0 International License, which permits use, sharing, adaptation, distribution and reproduction in any medium or format, as long as you give appropriate credit to the original author(s) and the source, provide a link to the Creative Commons licence, and indicate if changes were made. The images or other third party material in this article are included in the article's Creative Commons licence, unless indicated otherwise in a credit line to the material. If material is not included in the article's Creative Commons licence and your intended use is not permitted by statutory regulation or exceeds the permitted use, you will need to obtain permission directly from the copyright holder. To view a copy of this licence, visit http://creativecommons.org/licenses/by/4.0/ The Creative Commons Public Domain Dedication waiver (http://creativecommons.org/publicdomain/zero/1.0/) applies to the data made available in this article, unless otherwise stated in a credit line to the data. 
In this study, we present a case of a $P$. multocida induced peritoneal dialysis-related peritonitis, which is suspected to be caused through intimate contact with the household cat. Furthermore, we have reviewed 28 cases reported before and suggest more effective management on antibiotic treatment and the way of prevention.

\section{Case presentation}

On Aug. 9th, 2019, a 75-year-old man with end-stage renal disease (ESRD) on continuous ambulatory peritoneal dialysis (CAPD) for 5 years, which was $1.5 \%$ lowcalcium dialysate in a 4-to-5-h dwell three times every day and 2.5\% low-calcium dialysate in an 8-to-10-h dwell once every night, was admitted to the nephrology department with an 1-week history of abdominal pain and a cloudy peritoneal dialysis effluent (Fig. 1a). The patient had a past medical history of hypertension. For the reason that his pressure was lower than before, the antihypertensive drugs were stopped on admission.

Physical examination revealed an emaciated man with a blood pressure of $110 / 75 \mathrm{mmHg}$, a breath of 16 beats/ min, a pulse of 76 beats/min and a temperature of $36.8^{\circ} \mathrm{C}$. A head examination revealed no face edema. The cardiopulmonary exam was unremarkable. Abdominal examination revealed a soft abdomen, with moderate tenderness to palpation throughout particularly at the lower abdomen, moderate guarding with no rebound and normative bowel sounds. There was no discharge or erythema at the peritoneal dialysis catheter exit site. The tubing of the peritoneal dialysis catheter was intact and there was no macroscopic evidence of the peritoneal dialysis catheter damage.

Laboratory tests on the admitted day were available. The blood routine examination was as follows: white blood cell (WBC) count of $5.00 \times 109 / \mathrm{L}$, a neutrophil ratio of $78.2 \%$, lymphocyte ratio of $14.1 \%$, red blood cell $(\mathrm{RBC})$ count of $3.43 \times 1012 / \mathrm{L}$, hemoglobin of $83.10 \mathrm{~g} / \mathrm{L}$ and platelet count of $110 \times$ $109 / \mathrm{L}$. The biochemical routine examination was as follows: sodium $137.00 \mathrm{mmol} / \mathrm{L}$, potassium 2.97 $\mathrm{mmol} / \mathrm{L}$, chloride $95.0 \mathrm{mmol} / \mathrm{L}$, glucose $7.4 \mathrm{mmol} / \mathrm{L}$, blood urea nitrogen $21.76 \mathrm{mmol} / \mathrm{L}$ and creatinine $878.2 \mu \mathrm{mol} / \mathrm{L}$. BNP (natriuretic peptide B) was 135 $\mathrm{pg} / \mathrm{ml}$ and myoglobin was $402.4 \mathrm{ng} / \mathrm{ml}$. The initial peritoneal effluent analysis further revealed as follows: WBC count of $1537.0 \times 106 / \mathrm{L}$, chloride 105.8 $\mathrm{mmol} / \mathrm{L}$, glucose $20.8 \mathrm{mmol} / \mathrm{L}$, total protein $2.59 \mathrm{~g} / \mathrm{L}$, lactic dehydrogenase $(\mathrm{LDH}) 54.8 \mathrm{U} / \mathrm{L}$, adenosine deaminase (ADA) $0.9 \mathrm{U} / \mathrm{L}$. The changes of important laboratory results were being detected during the admitted period (Fig. 1c).

Based on the history, physical examination and laboratory results with the findings in the peritoneal dialysis fluid, a diagnosis of peritoneal dialysis-related peritonitis was confirmed. Besides related symptomatic treatments, the empiric antibiotic treatment was initiated with levofloxacin ( $0.5 \mathrm{~g}$ intravenously) every day, ceftazidime ( $0.25 \mathrm{~g}$ intraperitoneally) in a 3-h dwell four times every day and vancomycin ( $1.0 \mathrm{~g}$ intraperitoneally) in an 8-h dwell once at night every 5 days. Final culture of initial peritoneal effluent results indicated the organism was $P$. multocida, which was found to be sensitive to ampicillin/sulbactam, cefazolin, cefotaxime, cefoxitin, levofloxacin, ampicillin, cefuroxime, imipenem, ciprofloxacin, ceftazidime, meropenem, and cefoperazone/sulbactam, while in the blood there were no bacterial infections were having been found. According to the drugsensitive test, the intravenously antibiotic treatment was switched to meropenem (0.5 g intravenously) every $12 \mathrm{~h}$, with peritoneal antibiotic treatment still. After one-day treatment, the symptoms disappeared but the WBC count of peritoneal effluent was still above the normal level of the WBC counts, which reminded the infection remained existed. Therefore, Cefazidime was switched to amikacin $(200 \mathrm{mg}$ intraperitoneally) in a 3-h dwell four times every day and on Aug. 18th, intravenously meropenem was switched to cefoperazone/sulbactam ( $1.5 \mathrm{~g}$ intravenously) every $12 \mathrm{~h}$. And for the reason that the CAPD was noneffective and the peritoneal infection was not controlled, the patient was undergone temporary hemodialysis four times every week with imipenem/ cilastatin (500 mg intraperitoneally) in a 6-h dwell every day for continuing peritoneal antibiotic treatment. After 12-day antibiotic treatment, the WBC count of peritoneal effluent was not significantly improved and the peritoneal effluent was still cloudy. When it was the deadline of the ISPD guideline recommending to hemodialysis, the patient firmly refused the lasting hemodialysis and asked for a further treatment. According to the drug-sensitive results and reviewed case reports (Table 1), the patient was switched to ampicillin/sulbactam (3 g intravenously) twice every day. The WBC count of peritoneal effluent was markedly improved and the antibiotic treatment was continued until the WBC count of the peritoneal effluent was below $100 \times 106 / \mathrm{L}$ and the PD effluent was clear, which revealed the infection was controlled (Fig. 1b, c). During the treatment, the patient was undergone temporary hemodialysis 12 times to maintain the function of excretion. When the infection was controlled and the function of CAPD recovered, the temporary hemodialysis was stopped and the patient was returned to CAPD. The patient discharged after using ampicillin/sulbactam for 17 days and continued amoxicillin ( $0.25 \mathrm{~g}$ orally) three times a day for another 6 days. The detail key dates of 

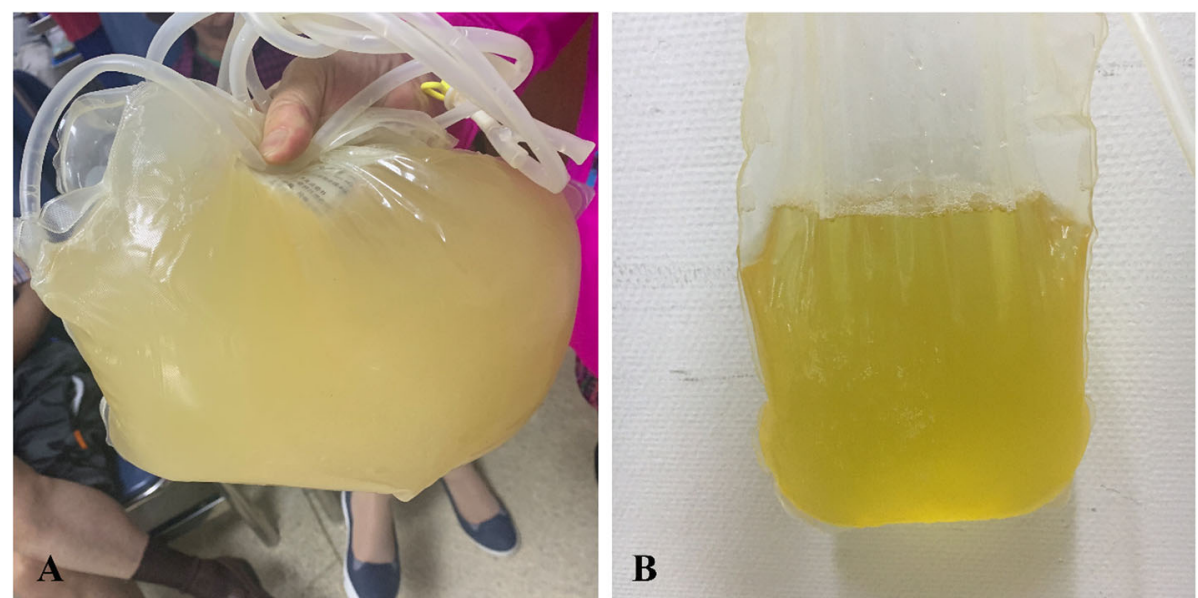

Antibotic treatment

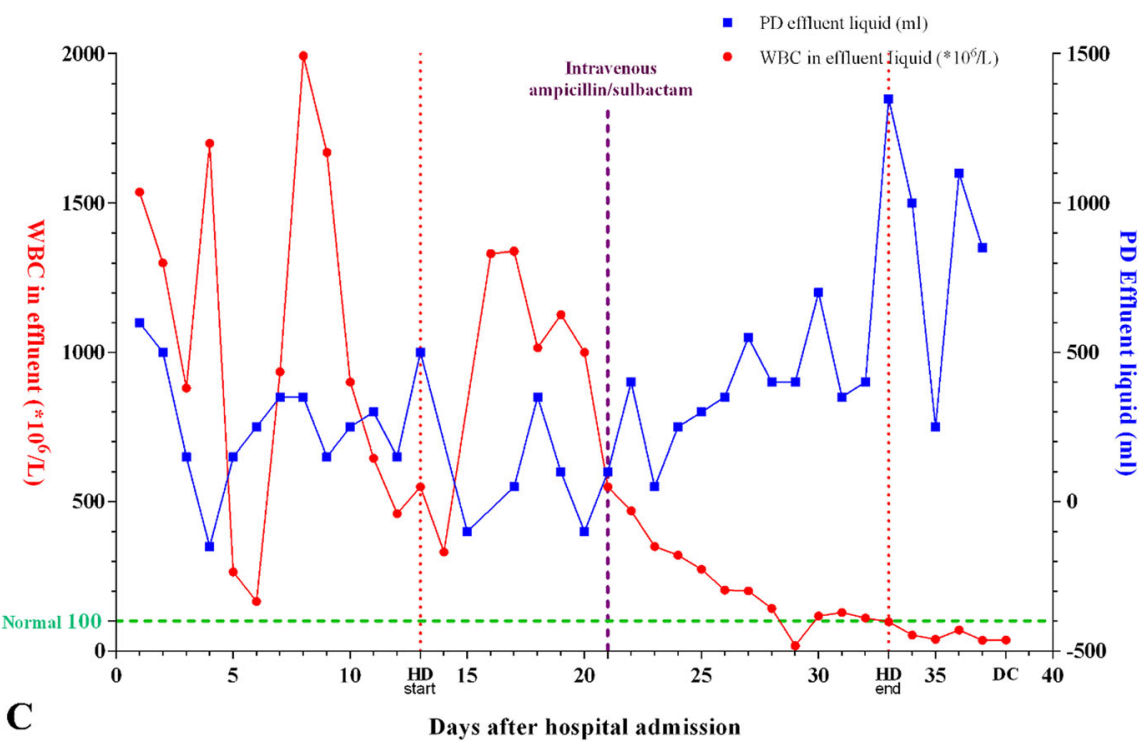

Fig. 1 The character of PD effluent. a The effluent collected on the day of admission. $\mathbf{b}$ The effluent collected to compare on the day of discharge. c Antibiotic treatment after hospital admission. At the early stage of treatment, we tried different types of antibiotics according drug sensation test. However, the effectiveness was not satisfied. After using ampicillin/sulbactam intravenously on Aug. 30th, the WBC count in PD effluent went down and the volume of the effluent went up, indicating an effective treatment. During the treatment, the patient had a period of temporary hemodialysis from the 13th day after admission to the day that WBC count of PD effluent was normal stably after 12 days ampicillin/ sulbactam treatment. HD: hemodialysis, DC: discharge

altering antibiotics and methods have been listed (Table 2).

The patient and his family were thankful to us and cooperated the further inquiry with us. On further inquiring, the patient reported that he had had a cat at home and when the patient did CAPD, the cat was usually playing with the tubing or contacting the patient during CAPD. However, during his peritoneal dialysis exchange, every step of peritoneal dialysis went all right, without noticing any abnormalities. The patient has suffered from peritoneal dialysisrelated peritonitis once in the near 2 years but the causes were not $P$. multocida. He did not report this incident in admission. After treatment, he continues CAPD to do well.

\section{Discussion and conclusion}

Patients with ESRD have chosen PD at home to become mainstream. Therefore, the pet-induced peritoneal dialysis-related peritonitis has been taken seriously. $P$. multocida is an animal-sourced Gram-negative coccobacillus, which is generally carried by cats [21]. Except for the usual sites like bit skin and soft tissue, $P$. multocida has been reported to be more high-frequency in patients undergoing PD. Reviewing the peritoneal dialysis-related peritonitis caused by $P$. multocida, we have found three main common occurrences that the patients recalled after $P$. multocida was cultured, which is now considered as risk factors (Fig. 2a, b, c, Table 1). Firstly, when the 
Table 1 Review of the cases in the previous literatures

\begin{tabular}{|c|c|c|c|c|c|c|c|c|}
\hline Case & Reference & Sex & Age $(Y r)$ & Main complains & $\begin{array}{l}\text { PD effluent } \\
\text { characters }\end{array}$ & $\begin{array}{l}\text { Animal } \\
\text { exposure }\end{array}$ & Effective treatments & Results \\
\hline 1 & $\begin{array}{l}\text { Rondon-Berrios, } \\
\text { H. [3] }\end{array}$ & Male & 38 & $\begin{array}{l}\text { Severe and diffuse abdominal } \\
\text { pain }\end{array}$ & Cloudy & $\begin{array}{l}\text { Household } \\
\text { cat }\end{array}$ & $\begin{array}{l}\text { Piperacillin/tazobactam (IV) } \\
\text { Vancomycin (IV) }\end{array}$ & Hemodialysis \\
\hline 2 & Campos, A. [4] & Male & 8 & Diffuse abdominal pain & Cloudy & $\begin{array}{l}\text { Household } \\
\text { hamster }\end{array}$ & Tobramycin (IP) & $\begin{array}{l}\text { Peritoneal } \\
\text { dialysis }\end{array}$ \\
\hline 3 & Sol, P. M. [5] & Female & 7 & Abdominal pain and vomiting & Cloudy & $\begin{array}{l}\text { Household } \\
\text { cat }\end{array}$ & Ampicillin (IP) & $\begin{array}{l}\text { Peritoneal } \\
\text { dialysis }\end{array}$ \\
\hline 4 & Paul, R. V. [2] & Female & 55 & Severe abdominal pain & Milk-colored & $\begin{array}{l}\text { Household } \\
\text { cat }\end{array}$ & $\begin{array}{l}\text { Vancomycin (IV) } \\
\text { gentamicin (IV) }\end{array}$ & $\begin{array}{l}\text { Peritoneal } \\
\text { dialysis }\end{array}$ \\
\hline 5 & Cooke, F. J. [6] & Female & 73 & Abdominal pain & Cloudy & $\begin{array}{l}\text { Household } \\
\text { cat }\end{array}$ & $\begin{array}{l}\text { Gentamicin (IP) } \\
\text { Ciprofloxacin (PO) }\end{array}$ & $\begin{array}{l}\text { Peritoneal } \\
\text { dialysis }\end{array}$ \\
\hline 6 & $\begin{array}{l}\text { Dresselaars, H. F. } \\
\text { [7] }\end{array}$ & Female & 62 & Mild abdominal discomfort & Turbid & $\begin{array}{l}\text { Household } \\
\text { cat }\end{array}$ & $\begin{array}{l}\text { Cotrimoxazole (IV) } \\
\text { Cefalotin (IP) }\end{array}$ & $\begin{array}{l}\text { Peritoneal } \\
\text { dialysis }\end{array}$ \\
\hline 7 & Giron, F. F. [8] & Male & 72 & Abdominal pain & Turbid & $\begin{array}{l}\text { Household } \\
\text { cat }\end{array}$ & $\begin{array}{l}\text { vancomycin (IP) } \\
\text { ceftazidime (IP) }\end{array}$ & $\begin{array}{l}\text { Peritoneal } \\
\text { dialysis }\end{array}$ \\
\hline 8 & Satomura, A. [9] & Male & 58 & Abdominal discomfort & Unknown & $\begin{array}{l}\text { Household } \\
\text { cat }\end{array}$ & $\begin{array}{l}\text { cefazolin (IP) } \\
\text { ceftazidime (IP) }\end{array}$ & $\begin{array}{l}\text { Peritoneal } \\
\text { dialysis }\end{array}$ \\
\hline 9 & Joh, J. [10] & Male & 55 & $\begin{array}{l}\text { Abdominal pain, nausea and } \\
\text { vomiting }\end{array}$ & Cloudy & $\begin{array}{l}\text { Household } \\
\text { cat }\end{array}$ & $\begin{array}{l}\text { Gentamicin (IP) Ampicillin/ } \\
\text { sulbactam (PO) }\end{array}$ & $\begin{array}{l}\text { Peritoneal } \\
\text { dialysis }\end{array}$ \\
\hline 10 & Kim, I. [11] & Female & 25 & Diffuse abdominal pain & Cloudy & $\begin{array}{l}\text { Household } \\
\text { cat }\end{array}$ & $\begin{array}{l}\text { Cefazolin (IP) } \\
\text { Gentamicin (IP) }\end{array}$ & $\begin{array}{l}\text { Peritoneal } \\
\text { dialysis }\end{array}$ \\
\hline 11 & $\begin{array}{l}\text { Loghman- } \\
\text { Adham, M. [12] }\end{array}$ & Female & 12 & Mild abdominal pain & Clear & $\begin{array}{l}\text { Household } \\
\text { cat }\end{array}$ & $\begin{array}{l}\text { Cephapirin (IP) } \\
\text { Gentamicin (IP) }\end{array}$ & $\begin{array}{l}\text { Peritoneal } \\
\text { dialysis }\end{array}$ \\
\hline 12 & MacKay, K. [13] & Male & 73 & Mild abdominal discomfort & Cloudy & $\begin{array}{l}\text { Household } \\
\text { cat }\end{array}$ & $\begin{array}{l}\text { Vancomycin (IP) } \\
\text { Ceftazadime (IP) }\end{array}$ & $\begin{array}{l}\text { Peritoneal } \\
\text { dialysis }\end{array}$ \\
\hline 13 & Nishina, M. [14] & Male & 45 & Abdominal pain & Cloudy & $\begin{array}{l}\text { Household } \\
\text { cat }\end{array}$ & $\begin{array}{l}\text { Vancomycin (IV) } \\
\text { Ceftazidime (IP) }\end{array}$ & $\begin{array}{l}\text { Peritoneal } \\
\text { dialysis }\end{array}$ \\
\hline 14 & $\begin{array}{l}\text { Freeman, A. F. } \\
{[15]}\end{array}$ & Female & 14 & Abdominal pain & Cloudy & $\begin{array}{l}\text { Household } \\
\text { hamster }\end{array}$ & $\begin{array}{l}\text { Vancomycin (IP) } \\
\text { Ceftazadime (IP) } \\
\text { Ampicillin/sulbactam (IV) }\end{array}$ & $\begin{array}{l}\text { Peritoneal } \\
\text { dialysis }\end{array}$ \\
\hline 15 & Kanaan, N. [16] & Female & 24 & $\begin{array}{l}\text { Diffuse abdominal pain and } \\
\text { nausea }\end{array}$ & Turbid & $\begin{array}{l}\text { Household } \\
\text { cat }\end{array}$ & $\begin{array}{l}\text { Vancomycin (IV) } \\
\text { Ciprofloxacin (PO) }\end{array}$ & $\begin{array}{l}\text { Peritoneal } \\
\text { dialysis }\end{array}$ \\
\hline 16 & Sillery, J. [17] & Female & 48 & General abdominal discomfort & Unknown & $\begin{array}{l}\text { Household } \\
\text { cat }\end{array}$ & Ampicillin (IV) & $\begin{array}{l}\text { Peritoneal } \\
\text { dialysis }\end{array}$ \\
\hline 17 & Elsey, R. M. [18] & Male & 25 & Abdominal pain and nausea & Cloudy & $\begin{array}{l}\text { Household } \\
\text { cat }\end{array}$ & $\begin{array}{l}\text { Cephradine (IP) } \\
\text { Gentamicin (IP) }\end{array}$ & $\begin{array}{l}\text { Peritoneal } \\
\text { dialysis }\end{array}$ \\
\hline 18 & $\begin{array}{l}\text { London, R. D. } \\
\text { [19] }\end{array}$ & Male & 54 & $\begin{array}{l}\text { Abdominal pain, nausea and } \\
\text { vomiting }\end{array}$ & Cloudy & $\begin{array}{l}\text { Household } \\
\text { cat }\end{array}$ & $\begin{array}{l}\text { Vancomycin (IV) } \\
\text { Gentamicin (IV) }\end{array}$ & $\begin{array}{l}\text { Peritoneal } \\
\text { dialysis }\end{array}$ \\
\hline 19 & $\begin{array}{l}\text { Mugambi, S. M. } \\
{[20]}\end{array}$ & Female & 36 & $\begin{array}{l}\text { Abdominal pain, nausea and } \\
\text { vomiting }\end{array}$ & Cloudy & $\begin{array}{l}\text { Household } \\
\text { cat }\end{array}$ & $\begin{array}{l}\text { Vancomycin (IV, IP) } \\
\text { Gentamicin (IV, IP) }\end{array}$ & $\begin{array}{l}\text { Peritoneal } \\
\text { dialysis }\end{array}$ \\
\hline 20 & $\begin{array}{l}\text { Poliquin, P. G. } \\
\text { [21] }\end{array}$ & Female & 28 & Severe abdominal pain & Cloudy & $\begin{array}{l}\text { Household } \\
\text { cat }\end{array}$ & $\begin{array}{l}\text { Cefazolin (IP) } \\
\text { Tobramycin (IP) } \\
\text { Ceftazidime (IP) }\end{array}$ & $\begin{array}{l}\text { Peritoneal } \\
\text { dialysis }\end{array}$ \\
\hline 21 & $\begin{array}{l}\text { Poliquin, P. G. } \\
\text { [21] }\end{array}$ & Male & 37 & Abdominal pain & Cloudy & $\begin{array}{l}\text { Household } \\
\text { cat }\end{array}$ & $\begin{array}{l}\text { Cefazolin (IP) } \\
\text { Tobramycin (IP) }\end{array}$ & $\begin{array}{l}\text { Peritoneal } \\
\text { dialysis }\end{array}$ \\
\hline 22 & $\begin{array}{l}\text { Poliquin, P. G. } \\
\text { [21] }\end{array}$ & Male & 41 & $\begin{array}{l}\text { Abdominal pain, nausea, } \\
\text { vomiting and diarrhea }\end{array}$ & Cloudy & $\begin{array}{l}\text { Household } \\
\text { cat }\end{array}$ & $\begin{array}{l}\text { Cefazolin (IP) } \\
\text { Tobramycin (IP) }\end{array}$ & $\begin{array}{l}\text { Peritoneal } \\
\text { dialysis }\end{array}$ \\
\hline 23 & $\begin{array}{l}\text { Poliquin, P. G. } \\
\text { [21] }\end{array}$ & Female & 51 & $\begin{array}{l}\text { Abdominal pain, nausea and } \\
\text { vomiting. }\end{array}$ & Cloudy & $\begin{array}{l}\text { Household } \\
\text { cat }\end{array}$ & $\begin{array}{l}\text { Cefazolin (IP) } \\
\text { Tobramycin (IP) }\end{array}$ & $\begin{array}{l}\text { Peritoneal } \\
\text { dialysis }\end{array}$ \\
\hline 24 & $\begin{array}{l}\text { Poliquin, P. G. } \\
\text { [21] }\end{array}$ & Female & 37 & $\begin{array}{l}\text { Abdominal pain, chills and } \\
\text { diarrhea. }\end{array}$ & Cloudy & $\begin{array}{l}\text { Household } \\
\text { cat }\end{array}$ & $\begin{array}{l}\text { Cefazolin (IP) } \\
\text { Ceftazidime (IP) }\end{array}$ & $\begin{array}{l}\text { Peritoneal } \\
\text { dialysis }\end{array}$ \\
\hline 25 & $\begin{array}{l}\text { Poliquin, P. G. } \\
\text { [21] }\end{array}$ & Female & 59 & $\begin{array}{l}\text { Abdominal pain, nausea and } \\
\text { vomiting }\end{array}$ & Unknown & $\begin{array}{l}\text { Household } \\
\text { cat }\end{array}$ & $\begin{array}{l}\text { Cefazolin (IP) } \\
\text { Tobramycin (IP) }\end{array}$ & $\begin{array}{l}\text { Peritoneal } \\
\text { dialysis }\end{array}$ \\
\hline 26 & Poliquin, P. G. & Female & 69 & Abdominal pain & Cloudy & Household & Cefazolin (IP) & Peritoneal \\
\hline
\end{tabular}


Table 1 Review of the cases in the previous literatures (Continued)

\begin{tabular}{|c|c|c|c|c|c|c|c|c|}
\hline Case & Reference & Sex & Age $(Y r)$ & Main complains & $\begin{array}{l}\text { PD effluent } \\
\text { characters }\end{array}$ & $\begin{array}{l}\text { Animal } \\
\text { exposure }\end{array}$ & Effective treatments & Results \\
\hline & [21] & & & & & cat & Tobramycin (IP) & dialysis \\
\hline 27 & $\begin{array}{l}\text { Van } \\
\text { Langenhove, G. } \\
\text { [22] }\end{array}$ & Female & 22 & Heavy abdominal pain & Cloudy & $\begin{array}{l}\text { Household } \\
\text { cat }\end{array}$ & $\begin{array}{l}\text { Vancomycin (IP) } \\
\text { Amikacin (IP) } \\
\text { Ciprofloxacin (PO) }\end{array}$ & $\begin{array}{l}\text { Peritoneal } \\
\text { dialysis }\end{array}$ \\
\hline 28 & Weiss, G. A. [23] & Male & 57 & Diffuse abdominal pain & Cloudy & $\begin{array}{l}\text { Household } \\
\text { cat }\end{array}$ & $\begin{array}{l}\text { Vancomycin (IP) } \\
\text { Ceftazadime (IP) }\end{array}$ & $\begin{array}{l}\text { Peritoneal } \\
\text { dialysis }\end{array}$ \\
\hline 29 & This case & Male & 75 & Abdominal pain & Cloudy & $\begin{array}{l}\text { Household } \\
\text { cat }\end{array}$ & Ampicillin/sulbactam (IV) & $\begin{array}{l}\text { Peritoneal } \\
\text { dialysis }\end{array}$ \\
\hline
\end{tabular}

IV Intravenously, IP Intraperitoneal, PO per os

PD machine was not used, the suspected pet played or rested near the machine, transmit the bacteria to pollute the machine, which in subsequent culture proved to carry bacteria from a pet. Secondly, when a patient was using the PD machine or was going to use it, the catheter was found to be bitten by a household pet, which could be stopped immediately. The last occurrence is when using the PD machine, the patient had intimate contact with the pet. Different from the reviewed case reports, our patient was infected while manual PD without a machine (Fig. 2d, e). During the process of filling, dwelling and draining, the patient might infect the tube and dialysis after contacting the suspected pet carried the bacteria. In the process of manual PD, the patient repeated from filling to draining for at least three times. At the next circulation of the PD process after infected, the bacteria might go into the abdomen and caused the peritoneal infection.

In all cases reviewed, the main clinical complaints were almost similar. The patients complained of a mildto-severe diffuse abdominal pain with vomiting and nausea usually and the PD effluent was always cloudy or turbid and laboratory tests revealed a high WBC count in PD effluent (Table 1). Clinical features of P. multocida

Table 2 Key altered dates of changing selected antibiotics and methods

\begin{tabular}{|c|c|c|c|}
\hline \multirow{2}{*}{$\begin{array}{l}\text { Key } \\
\text { Altered } \\
\text { Dates }\end{array}$} & \multicolumn{3}{|l|}{ Selected Antibiotics } \\
\hline & Orally & Intraperitoneally & Intravenously \\
\hline $\begin{array}{l}2019 / 8 / \\
9\end{array}$ & - & $\begin{array}{l}\text { Vancomycin ( } 1.0 \mathrm{~g} \text { intraperitoneally) in an } 8-\mathrm{h} \text { dwell once at } \\
\text { night and ceftazidime }(0.25 \mathrm{~g} \text { intraperitoneally) in a } 3-\mathrm{h} \\
\text { dwell four times every day }\end{array}$ & $\begin{array}{l}\text { Levofloxacin ( } 0.5 \mathrm{~g} \text { intravenously) every } \\
\text { day }\end{array}$ \\
\hline $\begin{array}{l}2019 / 8 / \\
15\end{array}$ & - & $\begin{array}{l}\text { Vancomycin ( } 1.0 \mathrm{~g} \text { intraperitoneally) in an 8-h dwell once at } \\
\text { night }\end{array}$ & - \\
\hline $\begin{array}{l}2019 / 8 / \\
18\end{array}$ & - & - & $\begin{array}{l}\text { Stop levofloxacin and change to } \\
\text { meropenem ( } 0.5 \mathrm{~g} \text { intravenously) every } \\
12 \mathrm{~h}\end{array}$ \\
\hline $\begin{array}{l}2019 / 8 / \\
19\end{array}$ & - & $\begin{array}{l}\text { Vancomycin ( } 1.0 \mathrm{~g} \text { intraperitoneally) in an } 8 \text {-h dwell once at } \\
\text { night, stop ceftazidime and change to Amikacin ( } 200 \mathrm{mg} \text { in- } \\
\text { traperitoneally) in a 3-h dwell four times every day }\end{array}$ & - \\
\hline $\begin{array}{l}2019 / 8 / \\
22\end{array}$ & - & Stop Amikacin & - \\
\hline $\begin{array}{l}2019 / 8 / \\
23\end{array}$ & - & - & $\begin{array}{l}\text { Stop meropenem and change to } \\
\text { cefoperazone/sulbactam ( } 1.5 \mathrm{~g} \\
\text { intravenously) every } 12 \mathrm{~h}\end{array}$ \\
\hline $\begin{array}{l}2019 / 8 / \\
26\end{array}$ & - & $\begin{array}{l}\text { Imipenem/cilastatin ( } 500 \text { mg intraperitoneally) in a 6-h dwell } \\
\text { every day }\end{array}$ & - \\
\hline $\begin{array}{l}2019 / 8 / \\
30\end{array}$ & - & - & $\begin{array}{l}\text { Stop cefoperazone/sulbactam and } \\
\text { change to ampicillin/sulbactam ( } 3 \mathrm{~g} \\
\text { intravenously) twice every day }\end{array}$ \\
\hline $\begin{array}{l}2019 / 9 / \\
11\end{array}$ & - & Stop imipenem/cilastatin & - \\
\hline $\begin{array}{l}2019 / 9 / \\
16\end{array}$ & $\begin{array}{l}\text { Discharge and continue } \\
\text { amoxicillin }(0.25 \mathrm{~g} \text { orally) three } \\
\text { times a day for another } 6 \text { days }\end{array}$ & - & - \\
\hline
\end{tabular}



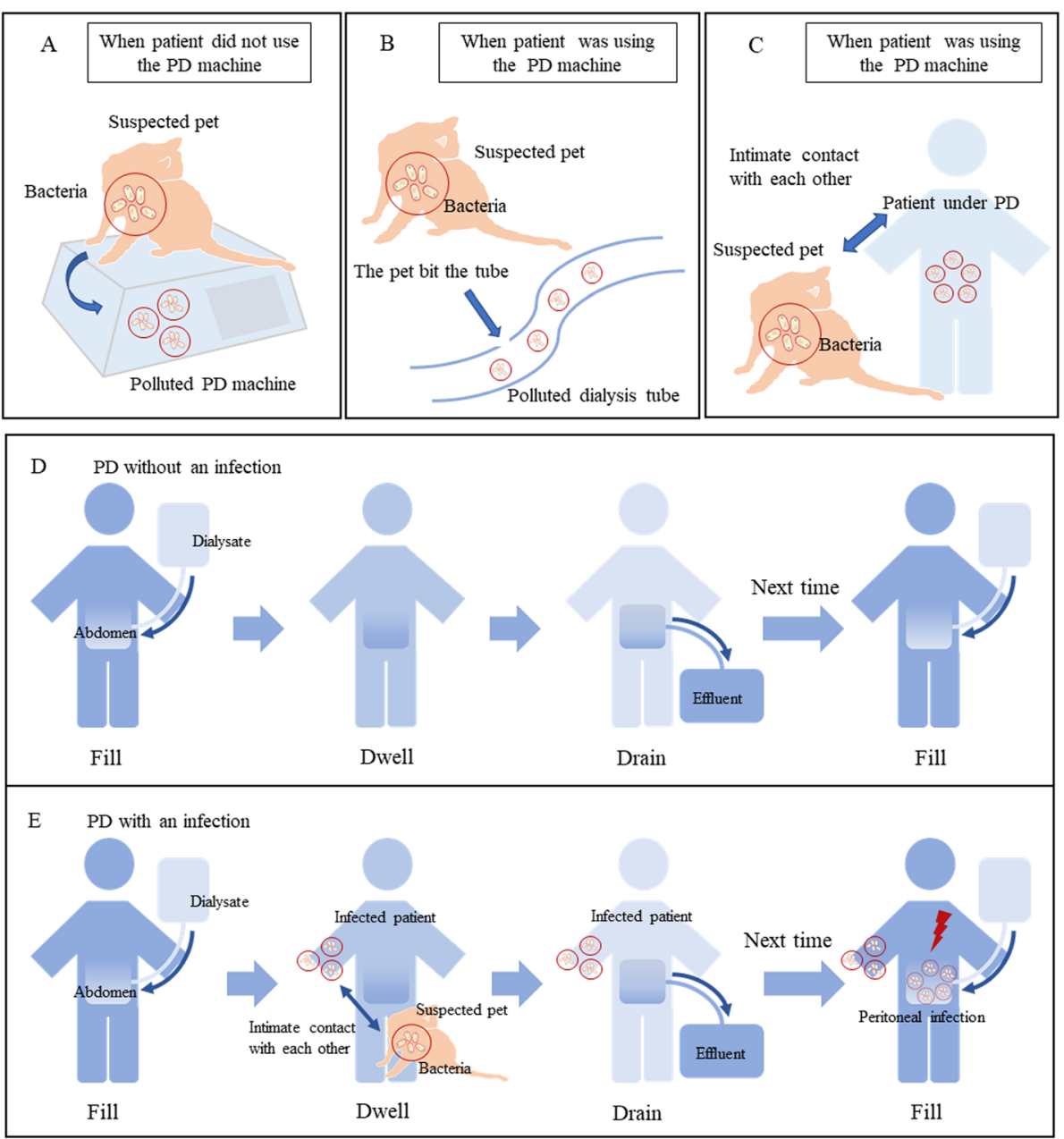

Fig. 2 1. Three main risk factors in reviewed cases. a When PD machine is not used, the suspected pet plays or rests near the machine transmit the bacteria to the machine. $\mathbf{b}$ When patient is using the PD machine or is going to use it, the catheter is found to be bit by household pet. $\mathbf{c}$ When using the PD machine, the patient had intimate contact with the pet. 2.Manual PD approach in this case. $\mathbf{d}$ The patient was under PD without an infection by suspected pet or other factors. e During manual PD, the patient might infect the tube or dialysate after contacting a suspected pet who carried bacteria in process of filling, dwelling and draining. For the next time of PD, the bacteria went into the abdomen and caused peritoneal infection

induced peritoneal dialysis-related peritonitis are generally not severe but only a few patients have a sensitive reaction, such as low blood pressure. Antibiotics should be initiated into the very beginning of the management of peritonitis, associated with the success of the treatment.

[1] The empiric treatments are recommended as a combination of one intraperitoneal antibiotic and one oral or intravenous antibiotic [24]. The antibiotics include penicillin, amoxycillin, fluoroquinolone, the third generation of cephalosporin cefepime, carbon penicillium alkene and compound sulfamethoxazole [25-28]. However, there are no clinical trials specifically demonstrate or evaluate the efficacy of different antibiotics for $P$. multocida related peritonitis. We collected the antibiotic selection and the drug-sensitive test is reviewed case reports and case series studies for the further recommendation (Fig. 3, Table 1). From the collection of each result of drug-sensitive test reviewed, $P$. multocida revealed a low drug resistance and gentamicin, ampicillin and penicillin could be initiated firstly in a selection of the antibiotics. The effectiveness of the recommended antibiotic combination should be detected according to the WBC counts in PD effluent and the antibiotic should be changed if the results are not satisfying. In the management of our patient, firstly we chose meropenem and cefoperazone/sulbactam intravenously and amikacin intraperitoneally with an unsatisfied WBC count in PD effluent. Then we changed treatment by using ampicillin/ sulbactam intravenously and the effectiveness was immediate. WBC count in PD effluent is sensitive to the effectiveness of antibiotics and after using ampicillin/ 


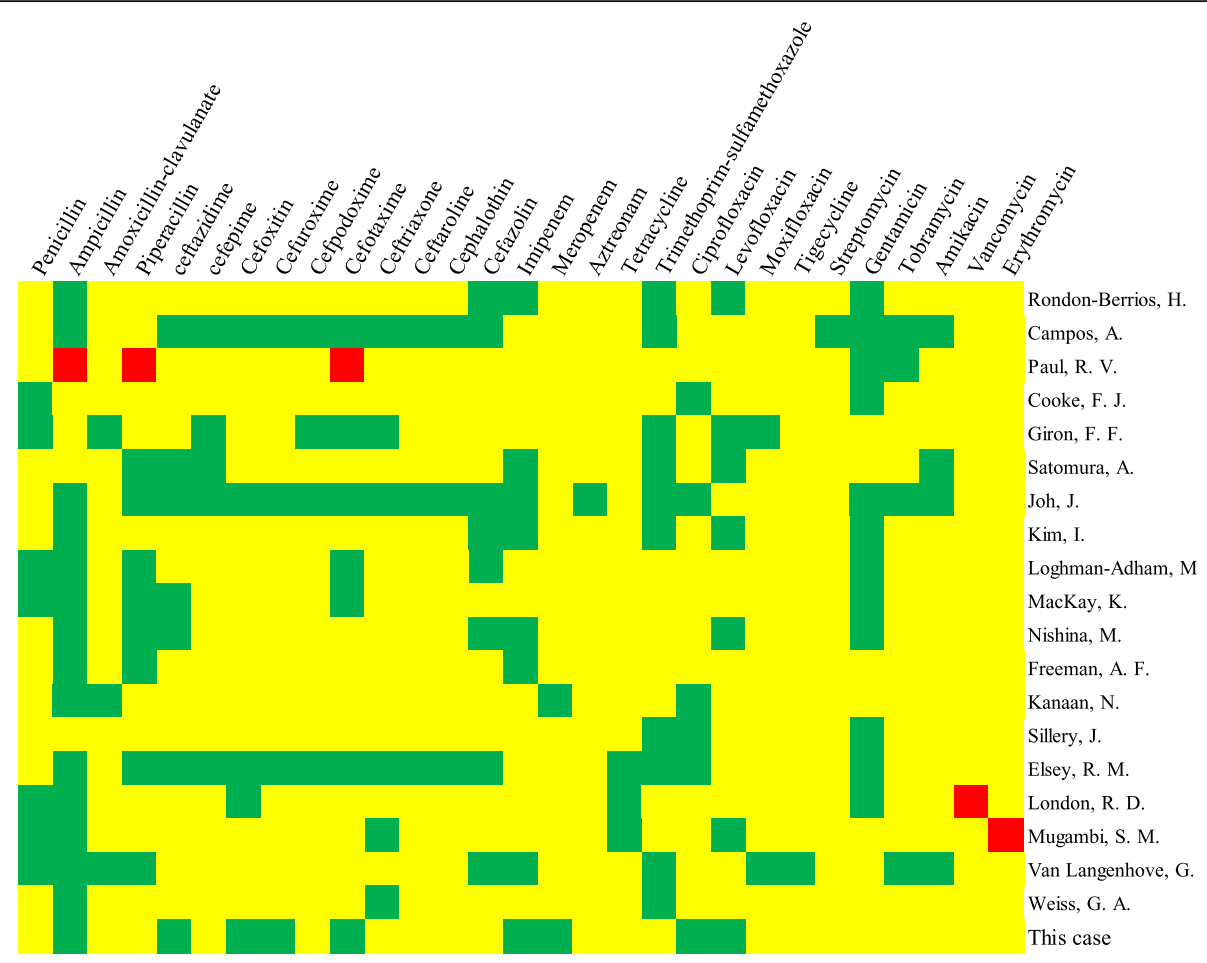

Drug sensitive test results of the reviewed cases. The horizontal coordinate is the antibiotics involved and the vertical coordinate is the reviewed cases which have done the valuable drug sensitive tests.

The green tube represents the bacteria is sensitive to the antibiotic.

The yellow tube represents the sensibility is unknown.

The red tube represents the bacteria is resistant to the antibiotic.

Fig. 3 Drug sensitive test results of the reviewed cases. The horizontal coordinate is the antibiotics involved and the vertical coordinate is the reviewed cases which have done the valuable drug sensitive tests. The green tube represents the bacteria is sensitive to the antibiotic.

The yellow tube represents the sensibility is unknown. The red tube represents the bacteria is resistant to the antibiotic

sulbactam the WBC count in PD effluent went down and the volume of PD effluent went up (Fig. 1c). Besides, in the use of antibiotics, residual renal function of the patient might be considered which is an extra way of antibiotic excretion [29].

In conclusion, $P$. multocida induced peritoneal dialysis-related peritonitis could be cured by proper antibiotic treatment, but the relapse has not been investigated yet. If individuals keep the pet away from the PD process, the infection route may be severed. It is also important to clean themselves between contact with pets and beginning PD. P. multocida induced peritoneal dialysis-related peritonitis does not need catheter removal and exchange with hemodialysis except long-time intractable peritonitis $[1,24,30]$. In our case, considering the family circumstance of the patient, we decided to continue PD with antibiotic treatment beyond the maximum duration recommended by ISPD guideline and finally we, with the patient, overcame the disease. This case is a brave attempt on treatment of those who can not leave from PD or alternate with hemodialysis. However, back to the whole treatment, we still have a deficiency. We have got the result of the drug-sensitive tests early but the follow-up treatment now seems to be a little inexperienced, such as the choice of antibioticdelivery way and the management of the antibiotics.

\section{Abbreviations}

P. multocida: Pasteurella multocida; ESRD: End stage renal disease; CAPD: Continuous ambulatory peritoneal dialysis; WBC: White blood cell; RBC: Red blood cell; LDH: Lactic dehydrogenase; ADA: Adenosine deaminase; BNP: Natriuretic peptide B; ISPD: International society for prenatal diagnosis; PD: Peritoneal dialysis; HD: Hemodialysis

\section{Acknowledgements}

Not applicable. 


\section{Authors' contributions}

$\mathrm{HM}$ collected the patient data and was a major contributor in writing the manuscript. SR, WY and MY treated the patient. JW, YYZ ${ }^{1}$ and $\mathrm{YJZ}^{2}$ helped to complete this work. All authors read and approved the final manuscript.

\section{Funding}

This study was supported by grants from the National Natural Science Foundation of China (No. 81970636) and Clinical Research Innovation Plan of Shanghai General Hospital (No. CTCCR-2018C09).

\section{Availability of data and materials}

Not applicable.

\section{Ethics approval and consent to participate} Not applicable.

\section{Consent for publication}

Written informed consent was obtained from the patient for publication of this case report and any accompanying images. A copy of the written consent is available for review by the Editor-in-Chief of this journal.

\section{Competing interests}

The authors declare that they have no competing interests.

\section{Author details}

'Shanghai Jiao Tong University School of Medicine, Shanghai, China. 2Department of Nephrology, Shanghai General Hospital, Shanghai Jiao Tong University School of Medicine, Shanghai 200080, China.

\section{Received: 28 November 2019 Accepted: 12 March 2020}

Published online: 19 March 2020

\section{References}

1. Bieber S, Mehrotra R. Peritoneal dialysis access associated infections. Adv Chronic Kidney Dis. 2019;26(1):23-9.

2. Paul RV, Rostand SG. Cat-bite peritonitis: Pasteurella multocida peritonitis following feline contamination of peritoneal dialysis tubing. Am J Kidney Dis. 1987;10(4):318-9.

3. Rondon-Berrios H, Trevejo-Nunez GJ. Pets or pest: peritoneal dialysis-related peritonitis due to Pasteurella multocida. J Microbiol Immunol Infect. 2010; 43(2):155-8.

4. Campos A, Taylor JH, Campbell M. Hamster bite peritonitis: Pasteurella pneumotropica peritonitis in a dialysis patient. Pediatr Nephrol (Berlin, Germany). 2000:15(1-2):31-2.

5. Sol PM, van de Kar NC, Schreuder MF. Cat induced Pasteurella multocida peritonitis in peritoneal dialysis: a case report and review of the literature. Int J Hyg Environ Health. 2013;216(2):211-3.

6. Cooke FJ, Kodjo A, Clutterbuck EJ, Bamford KB. A case of Pasteurella multocida peritoneal dialysis-associated peritonitis and review of the literature. Int J Infect Dis. 2004:8(3):171-4.

7. Dresselaars HF, Zwart B, Pettersson AM, Rijnsburger MC, Ho-dac-Pannekeet MM. Peritoneal dialysis-associated peritonitis of zoonotic origin, when minor gets major. Neth J Med. 2014;72(10):551-3.

8. Giron FF, Martin JMS, Gomez ER, Munoz SC, Carmelo FG, Gomez IG, Mora MTM, Escolano FJR, Chaparro CG. Simultaneous Streptococcus canis and Pasteurella multocida peritonitis in a peritoneal dialysis patient. Perit Dial Int. 2017;37(4):483-4.

9. Satomura A, Yanai M, Fujita T, Arashima Y, Kumasaka K, Nakane C, Ito K, Fuke $Y$, Maruyama T, Maruyama N, et al. Peritonitis associated with Pasteurella multocida: molecular evidence of zoonotic etiology. Ther Apher Dial. 2010;14(3):373-6.

10. Joh J, Padmanabhan R, Bastani B. Pasteurella multocida peritonitis following cat bite of peritoneal dialysis tubing. With a brief review of the literature. Am J Nephrol. 1998;18(3):258-9.

11. Kim I, Kim YW, Chung S, Yoon HE, Shin SJ. Cat-induced Pasteurella multocida peritonitis in continuous ambulatory peritoneal dialysis. Kidney Res Clin Pract. 2014;33(1):65-7.

12. Loghman-Adham M. Pasteurella multocida peritonitis in patients undergoing peritoneal dialysis. Pediatr Nephrol (Berlin, Germany). 1997;11(3):353-4.

13. MacKay K, Brown L, Hudson F. Pasteurella multocida peritonitis in peritonea dialysis patients: beware of the cat. Perit Dial Int. 1997;17(6):608-10.
14. Nishina M, Yanagi H, Koizumi M, Kimura M, Kakuta T, Endoh M, Fukagawa M, Takagi A. Pasteurella multocida peritonitis associated with a cat in a peritoneal dialysis patient using an automated cycler device. CEN Case Rep. 2012;1(2):73-6.

15. Freeman AF, Zheng XT, Lane JC, Shulman ST. Pasteurella aerogenes hamster bite peritonitis. Pediatr Infect Dis J. 2004;23(4):368-70.

16. Kanaan N, Gavage P, Janssens M, Avesani V, Gigi J, Goffin E. Pasteurella multocida in peritoneal dialysis: a rare cause of peritonitis associated with exposure to domestic cats. Acta Clin Belg. 2002;57(5):254-6.

17. Sillery J, Hargreaves J, Marin P, Lerma E, Kuznia C, Abbe C. Pasteurella multocida peritonitis: another risk of animal-assisted therapy. Infect Control Hosp Epidemiol. 2004;25(1):5-6

18. Elsey RM, Carson RW, DuBose TD Jr. Pasteurella multocida peritonitis in an HIV-positive patient on continuous cycling peritoneal dialysis. Am J Nephrol. 1991;11(1):61-3.

19. London RD, Bottone EJ. Pasteurella multocida: zoonotic cause of peritonitis in a patient undergoing peritoneal dialysis. Am J Med. 1991:91(2):202-4.

20. Mugambi SM, Ullian ME. Bacteremia, sepsis, and peritonitis with Pasteurella multocida in a peritoneal dialysis patient. Perit Dial Int. 2010;30(3):381-3.

21. Poliquin PG, Lagace-Wiens $P$, Verrelli M, Allen DW, Embil JM. Pasteurella species peritoneal dialysis-associated peritonitis: household pets as a risk factor. Can J Infect Dis Med Microbiol. 2015:26(1):52-5.

22. Van Langenhove G, Daelemans R, Zachee P, Lins RL. Pasteurella multocida as a rare cause of peritonitis in peritoneal dialysis. Nephron. 2000:85(3):283-4.

23. Weiss GA, Panesar M. Pasteurella multocida peritonitis with bacteremia on initiation of peritoneal dialysis. Perit Dial Int. 2012:32(3):363-4.

24. Liakopoulos V, Nikitidou O, Kalathas T, Roumeliotis S, Salmas M, Eleftheriadis T. Peritoneal dialysis-related infections recommendations: 2016 update. What is new? Int Urol Nephrol. 2017:49(12):2177-84.

25. Lion C, Conroy MC, Carpentier AM, Lozniewski A. Antimicrobial susceptibilities of Pasteurella strains isolated from humans. Int J Antimicrob Agents. 2006;27(4):290-3.

26. Citron DM, Warren YA, Fernandez HT, Goldstein MA, Tyrrell KL, Goldstein EJ. Broth microdilution and disk diffusion tests for susceptibility testing of Pasteurella species isolated from human clinical specimens. J Clin Microbiol. 2005;43(5):2485-8

27. Goldstein EJ, Citron DM, Merriam CV, Warren YA, Tyrrell KL, Fernandez HT. Comparative in vitro activity of faropenem and 11 other antimicrobial agents against 405 aerobic and anaerobic pathogens isolated from skin and soft tissue infections from animal and human bites. J Antimicrob Chemother. 2002;50(3):411-20.

28. Goldstein EJ, Citron DM, Merriam CV, Warren YA, Tyrrell KL, Fernandez HT. In vitro activities of garenoxacin (BMS-284756) against 170 clinical isolates of nine Pasteurella species. Antimicrob Agents Chemother. 2002;46(9):3068-70

29. Barretti P, Doles JV, Pinotti DG, El Dib R. Efficacy of antibiotic therapy for peritoneal dialysis-associated peritonitis: a proportional meta-analysis. BMC nfect Dis. 2014;14:445.

30. Troidle L, Finkelstein F. Treatment and outcome of CPD-associated peritonitis. Ann Clin Microbiol Antimicrob. 2006;5:6

\section{Publisher's Note}

Springer Nature remains neutral with regard to jurisdictional claims in published maps and institutional affiliations.

Ready to submit your research? Choose BMC and benefit from:

- fast, convenient online submission

- thorough peer review by experienced researchers in your field

- rapid publication on acceptance

- support for research data, including large and complex data types

- gold Open Access which fosters wider collaboration and increased citations

- maximum visibility for your research: over $100 \mathrm{M}$ website views per year

At BMC, research is always in progress.

Learn more biomedcentral.com/submission 